\title{
Indoor Air Pollution with Fine Particles and Implications for Workers' Health in Dental Offices: A Brief Review
}

\author{
Diana Mariana Cocârţă ${ }^{1, *}$, Mariana Prodana ${ }^{2, *}$, Ioana Demetrescu ${ }^{2,3}$ (D) Patricia Elena Maria Lungu 2 \\ and Andreea Cristiana Didilescu 4 (iD
}

1 Department of Energy Production and Use, Splaiul Independentei No. 313, Faculty of Power Engineering, University POLITEHNICA of Bucharest, 006042 Bucharest, Romania

2 Department of General Chemistry, University Politehnica of Bucharest, 1-7 Gh Polizu Str, 011061 Bucharest, Romania; I_demetrescu@chim.upb.ro (I.D.); patricialungu@gmail.com (P.E.M.L.)

3 Academy of Romanian Scientists, 3 Ilfov, 050044 Bucharest, Romania

4 Division of Embryology, Faculty of Dental Medicine, “Carol Davila" University of Medicine and Pharmacy, 8 , Blvd Eroilor Sanitari, 050474 Bucharest, Romania; andreea.didilescu@umfcd.ro

* Correspondence: diana.cocarta@upb.ro (D.M.C.); mariana.prodana@upb.ro (M.P.)

Citation: Cocârță, D.M.; Prodana, M.; Demetrescu, I.; Lungu, P.E.M.; Didilescu, A.C. Indoor Air Pollution with Fine Particles and Implications for Workers' Health in Dental Offices: A Brief Review. Sustainability 2021, 13, 599. https://doi.org/10.3390/su 13020599

Received: 13 October 2020 Accepted: 7 January 2021 Published: 10 January 2021

Publisher's Note: MDPI stays neutral with regard to jurisdictional clai$\mathrm{ms}$ in published maps and institutional affiliations.

Copyright: (C) 2021 by the authors. Licensee MDPI, Basel, Switzerland. This article is an open access article distributed under the terms and conditions of the Creative Commons Attribution (CC BY) license (https:// creativecommons.org/licenses/by/ $4.0 /)$.
Abstract: (1) Background: Indoor air pollution can affect the well-being and health of humans. Sources of indoor pollution with particulate matter (PM) are outdoor particles and indoor causes, such as construction materials, the use of cleaning products, air fresheners, heating, cooking, and smoking activities. In 2017, according to the Global Burden of Disease study, 1.6 million people died prematurely because of indoor air pollution. The health effects of outdoor exposure to PM have been the subject of both research and regulatory action, and indoor exposure to fine particles is gaining more and more attention as a potential source of adverse health effects. Moreover, in critical situations such as the current pandemic crisis, to protect the health of the population, patients, and staff in all areas of society (particularly in indoor environments, where there are vulnerable groups, such as people who have pre-existing lung conditions, patients, elderly people, and healthcare professionals such as dental practitioners), there is an urgent need to improve long- and short-term health. Exposure to aerosols and splatter contaminated with bacteria, viruses, and blood produced during dental procedures performed on patients rarely leads to the transmission of infectious agents between patients and dental health care staff if infection prevention procedures are strictly followed. On the other hand, in the current circumstances of the pandemic crisis, dental practitioners could have an occupational risk of acquiring coronavirus disease as they may treat asymptomatic and minimally symptomatic patients. Consequently, an increased risk of SARS-CoV-2 infection could occur in dental offices, both for staff that provide dental healthcare and for other patients, considering that many dental procedures produce droplets and dental aerosols, which carry an infectious virus such as SARS-CoV-2. (2) Types of studies reviewed and applied methodology: The current work provides a critical review and evaluation, as well as perspectives concerning previous studies on health risks of indoor exposure to PM in dental offices. The authors reviewed representative dental medicine literature focused on sources of indoor PM10 and PM2.5 (particles for which the aerodynamic diameter size is respectively less than 10 and $2.5 \mu \mathrm{m}$ ) in indoor spaces (paying specific attention to dental offices) and their characteristics and toxicological effects in indoor microenvironments. The authors also reviewed representative studies on relations between the indoor air quality and harmful effects, as well as studies on possible indoor viral infections acquired through airborne and droplet transmission. The method employed for the research illustrated in the current paper involved a desk study of documents and records relating to occupational health problems among dental health care providers. In this way, it obtained background information on both the main potential hazards in dentistry and infection risks from aerosol transmission within dental offices. Reviewing this kind of information, especially that relating to bioaerosols, is critical for minimizing the risk to dental staff and patients, particularly when new recommendations for COVID-19 risk reduction for the dental health professional community and patients attending dental clinics are strongly needed. (3) Results: The investigated studies and reports obtained from the medical literature showed that, even if there are a wide number of studies on indoor human exposure to fine particles and health effects, more 
deep research and specific studies on indoor air pollution with fine particles and implications for workers' health in dental offices are needed. As dental practices are at a higher risk for hazardous indoor air because of exposure to chemicals and microbes, the occupational exposures and diseases must be addressed, with special attention being paid to the dental staff. The literature also documents that exposure to fine particles in dental offices can be minimized by putting prevention into practice (personal protection barriers such as masks, gloves, and safety eyeglasses) and also keeping indoor air clean (e.g., high-volume evacuation, the use of an air-room-cleaning system with high-efficiency particulate filters, and regularly maintaining the air-conditioning and ventilation systems). These kinds of considerations are extremely important as the impact of indoor pollution on human health is no longer an individual issue, with its connections representing a future part of sustainability which is currently being redefined. These kinds of considerations are extremely important, and the authors believe that a better situation in dentistry needs to be developed, with researchers in materials and dental health trying to understand and explain the impact of indoor pollution on human health.

Keywords: indoor air quality; fine particles; indoor pollution; SARS-CoV-2; occupational exposure; dentistry workers

\section{Introduction}

After the identification of the severe acute respiratory syndrome coronavirus 2 (SARSCoV-2) in humans in Wuhan, China, at the end of 2019, as a new viral group strain, this virus spread all over the world [1]. This was possible because of the rapid virus transmission that can take place via direct and indirect contact, through respiratory droplets and airborne transmission [2,3]. Simultaneously, different research studies [4-7] on various aspects of SARS-CoV-2, such as airborne virus sampling, identification methods, spreading, and control approaches, have been conducted, in order to prevent coronavirus transmission. Currently, in the pandemic, different groups of researchers are focused on testing methods and epidemiological and pharmacological studies, which are being widely investigated in order to sustain prevention and organizational methods for SARS-CoV-2 transmission control [8,9]. While no specific antiviral drug is available for the treatment of the coronavirus disease (COVID-19) [10-12], and the vaccines produced are just beginning to take effect in protecting people against the novel coronavirus SARS-CoV-2, there are different opinions, observations, and assumptions. Examples of assumptions based on preliminary studies are those made about the correlation between exceedance of the air quality limits for PM10 and an increasing number of hospitalizations because of COVID-19 disease, about the existence of a link between air pollution with PM2.5 and the level of lethality of COVID-19 [13], and concerning the fact that airborne particulate matter can act as a vehicle for transmission of the SARS-CoV-2 virus [14,15]. On the other hand, considering that the COVID-19 pandemic is currently ongoing, it is still too early to generalize conclusions based on a limited number of observations. Therefore, these currently remain hypotheses to be verified over time.

What is certainly known at this time is that air pollution, which is mostly generated by anthropogenic activity, has become an overwhelming issue, taking into consideration the effects on human health and climate change over a period of years. World Health Organization (WHO) data show that 9 out of 10 people breathe in high levels of polluted air and seven to eight million premature deaths occur worldwide each year, as an effect of exposure to both ambient and indoor air pollution [16]. An accurate estimation of air pollution is a function of a specific country's industrial aspects and prevention level, being greater in mining areas such as New South Wales, Australia [17], or in high-traffic-volume on both rural and urban roadways $[18,19]$. On the other hand, indoor air pollution is one of the world's largest environmental issues.

Regarding the action of viruses, it must be mentioned that, after the first discovered virus in 1901, statistically, in each year, three or four new viruses have been found [20]. The current pandemic increased both the need to identify and improve the gaps in knowledge 
about this field; specifically, knowledge on the behavior of airborne particles of a biological origin containing viruses and the indoor air quality of hospitals and healthcare facilities. In this context, particulates from indoor pollution and their source measurements and health effects have become more and more important. The present paper presents a comparative review of sources, properties, measurements, and negative effects on human health because of fine particle air pollution, with particular attention being paid to the harmful effects of indoor air quality pollution on dental staff in the framework of dental offices.

According to the United States Occupational Safety and Health Administration, in the framework of the actual pandemic crisis, dentistry is classified as one of the very high-risk occupations for transmission of the disease, due to the aerosols produced during dental procedures [21]. Aerosol, splatter, and droplet generation occurs throughout dental procedures. According to the research conducted by Harrel in 2004 [22], potential sources of airborne contamination during dental treatment are dental instrumentation, saliva and respiratory sources, and the operative site. Concerning the dental instrumentation, the same author has indicated that routine cleaning and sterilization procedures should eliminate contamination [22]. Normal dental practices with the potential to aerosolize saliva will cause airborne contamination with organisms from different sources, such as fluids in the mouth; dental plaque, both supragingival and in the periodontal pocket; nose; throat; and respiratory tract [22,23]. Despite the fact that Mycobacterium tuberculosis (the bacterium that causes tuberculosis (TB)) was considered the most serious potential threat present in aerosols [22,24], recent studies [25] simulating the transmission of coronaviruses, the measles virus, the influenza virus, Mycobacterium tuberculosis, and Legionella pneumophila in dental clinics via mathematical modeling indicated that the risk for the transmission of the bacteria M. tuberculosis and L. pneumophila was lower with respect to the risk for the measles virus transmission [25]. In the framework of the study, scenario-specific analyses considered high patient infectiousness, the absence of respiratory protection, and poor indoor air quality. These circumstances conducted to high transmission probabilities estimated measles virus of $100 \%$, for coronaviruses $99.4 \%$, influenza virus, $89.4 \%$, and for $M$. tuberculosis, $84.0 \%$. An important parameter indicated for the indoor airborne transmission of viruses in the dental clinic is the $\mathrm{CO}_{2}$ level [25]. On the other hand, the $\mathrm{CO}_{2}$ level corresponding to a given COVID-19 infection risk has not yet been identified [26]. Therefore, further research for obtaining a deeper understanding of the transmission of severe acute respiratory syndrome coronavirus 2 (SARS-CoV-2) from aerosols generated by dental practices is needed.

The operative site, because of the instrumentation used, such as dental handpieces, ultrasonic scalers, air polishers, and air abrasion units, produces visible aerosols [22,27]. The material removed from the operative site becomes aerosolized by the action of the rotary instrument, ultrasonic vibrations, or the combined action of water sprays and compressed air [22]. Therefore, a significant number of aerosols are produced, which reach health care dental staff and patients.

The U.S. Environmental Protection Agency (US EPA) has demonstrated that indoor air pollution can be two to five times worse than typical outdoor air pollution [28]. Indoor air pollution with different chemicals, including gases, volatile organic compounds (VOCs), particulate matter (PM), fibers, and organic and inorganic contaminants [29], can negatively affect the Indoor Air Quality (IAQ). Moreover, various particles of biological origin carry infectious microbes and microbial metabolites also affecting the IAQ. This frequently happens in dental offices, as was previously evidenced by illustrating sources of aerosols produced during dental procedures, as well as because of the poor air quality resulting from the use of equipment and disinfectants. Consequently, both particles of biological origin and existing chemicals can pose significant risks to the health, safety, and wellbeing of dental staff and patients. Potential health hazards caused by the air quality problems in dentistry are described in the second part of the present paper.

The objective of this review was to provide an overview of the evidence in the literature on indoor air pollution with fine particles in dental healthcare and their effects on dental 
staff. During the review, factors affecting the IAQ in dentistry and the main potential hazards for dental workers were considered. In this context, the transmission of SARS-CoV2 from aerosols generated by dental practices was also discussed. Therefore, in the current research, a review of dental literature concerning indoor pollution with fine particles was performed. In different databases, including PubMed, Medline, Web of Science, and Google Scholar (but not limited to these), key words such as indoor air pollution, dental staff, hazards, aerosols, and SARS-CoV-2 [30] were used in different combinations, in order to obtain references for the review. A total of 270 papers were initially identified. Of these, 131 articles were selected for review as they fitted the inclusion/exclusion criteria for this study. Included studies in the framework of the present research must have been published in the last 10 years (only 32\% of the reviewed papers were published before 2016, while $20 \%$ of the reviewed papers were published in the last 2 years). Exclusion criteria for the reviewed papers were studies published more than 10 years ago (with one exception) and studies published in a language other than English.

\section{Factors Affecting the Indoor Air Quality}

\subsection{Outdoor Sources of PM10 and PM2.5 Pollution}

Particulate matter emissions are formed in the atmosphere in different ways. Examples of this are physicochemical reactions (such as distillation, combustion, calcination, condensation, and sublimation), which are called fumes; the disintegration of a parent material (crushing, grinding, and blasting), if considering dust; incomplete combustion (called smoke); and vapor condensation that produces a liquid particulate (mist and fog), or releases biological organisms contained in solid or liquid particulate (bioaerosols) [31]. Exposure to PM pollution outdoors has been extensively investigated compared to pollution in indoor environments, even though it was recently evidenced that the level of indoor PM concentrations is higher than that of outdoor PM [32].

The main sources of outdoor pollution are transport, non-renewable energy sources, residential heating systems, waste incineration, and other industrial processes. Traffic is the leading source of pollution, mainly occurring in urban agglomerations. Emissions from this source consist of both gaseous compounds and volatile organics (benzene), and PM10- and PM2.5 containing metals. The greatest impact is observed in areas with overcrowded traffic lanes, where the dispersion of pollutants is difficult to achieve [33,34]. A major contribution to particulate pollution also arises from construction activities, such as building or road rehabilitation [35]. Therefore, the anthropogenic sources are the main contributors to air pollution with fine particles, especially in urban areas [36].

Both indoor and outdoor particulate matter concentrations and their dynamic trend are linked to meteorological conditions and the performed activities. The concentration of particulates of different sizes was found to be the highest in wintertime, especially due to anthropogenic activities; other factors affecting air pollution are wind conditions (for instance, a low wind speed may promote a longer permanence of particles in polluted air of cities) and high humidity levels in ambient air compared with other seasons. A study in this regard was presented by Massey in 2012, illustrating such trends based on monthly and seasonal variations of indoor and outdoor particulate concentrations in India considering ordinary activities of the people [32]. Outdoor and indoor fine particle concentrations for similar temperatures and activities are illustrated in Table 1 [32].

Table 1. Air pollution indicators (particulate matter PM10 and PM2.5) in Northern India (Agra).

\begin{tabular}{|c|c|c|c|c|}
\hline Indicator & Category & India Outdoor & India Indoor & Observations \\
\hline PM2.5 $\mu \mathrm{g} \mathrm{m}^{-3}$ & $\begin{array}{c}\text { Annual average } \\
\text { concentration } 2012\end{array}$ & 160 & 161 & \multirow{2}{*}{$\begin{array}{l}\text { Health effects on occupants of the houses } \\
\text { with a higher concentration level of both } \\
\text { PM2.5 and PM10 were more aggressive }\end{array}$} \\
\hline PM10 $\mu \mathrm{g} \mathrm{m}^{-3}$ & $\begin{array}{c}\text { Annual average } \\
\text { concentration } 2012\end{array}$ & 255 & 247 & \\
\hline
\end{tabular}


The atmospheric particulates sampled in China for four months in order to compare chemical compositions and sources for PM2.5 and PM10 indicated mean levels of PM2.5 and PM10 of 81 and $109 \mu \mathrm{g} / \mathrm{m}^{3}$, respectively [37]. Results published in 2018 concerning PM2.5 and PM10 air pollution showed concentrations higher than the health threshold levels regulated by national and international standards [38]. During the sampling period, the Air Quality Index (AQI) was strongly correlated with PM2.5 (Pearson's coefficient $r=0.94$ ) rather than PM10 concentrations. The PM2.5/PM10 ratios were approximately 0.7, revealing fine particle pollution.

\subsection{Indoor Sources of PM10 and PM2.5}

WHO has estimated that almost half of the world's population (about 3 billion people) uses polluting technologies and solid fuels for cooking, heating, and lighting, which are a major source of air pollution for indoor environments [39]. Sources of household PM are both indoor and outdoor sources [40]. Consequently, the quality of the indoor air is influenced by the outdoor air quality [41] and the indoor sources, such as heating/cooling, cooking facilities using fossil fuels (oil, gas, kerosene, coal, and wood), smoking, building materials and furniture, carpets, cleaning products, maintenance products, and personal care [42]. Office equipment, including computers, printers, and machines, was added to the previously mentioned sources of indoor air pollution, in accordance with the activities that take place in the indoor environment. Reported emissions from the illustrated sources are volatile and semi volatile organic chemicals (VOCs and SVOCs, respectively), and ozone and particulate matter. Pollutants such as phthalate esters, brominated flame retardants, organophosphate flame retardants, and polycyclic aromatic hydrocarbons (PAHs), together with pets and an inadequate humidity that can cause the development of mold, are significant contributors to negative effects on a human's health because of indoor exposure to air pollutants [43]. Specifically, unlike the external environment, some important indoor pollutants are those from biological sources (animals, pollen, pathogens through water vapor, air conditioning systems, humidifiers, and carpets). Results of investigations in school environments have shown that the particulate matter has a bacterial content which is much higher when students are present in classes compared to the values recorded when the classes are empty; the same trend was observed by the authors concerning the presence of fungal species $[43,44]$.

Scientific works were conducted concerning indoor air pollution and people's exposure in different environments [45]. Generally, indoor PM10 contains different levels of As, $\mathrm{Ni}, \mathrm{Cd}, \mathrm{Pb}, \mathrm{Al}, \mathrm{B}, \mathrm{Zn}, \mathrm{Mg}, \mathrm{Sb}, \mathrm{F}^{-}, \mathrm{ClO}^{2-}, \mathrm{NO}^{3-}$, and $\mathrm{SO}_{4}{ }^{2-}$, while indoor PM2.5 contains 50\% organic carbon, 3\% elemental carbon, about 30\% sulphates and nitrates, and $15 \%$ ammonium ion and water; the total metal content of PM is about $1 \%(2 / 3$ iron, zinc, vanadium, titanium, silver, copper, manganese, and chromium) [46]. It should be emphasized that although they are present in small quantities, metals have an important negative effect on human health.

In addition to the dentists' indoor exposure to different chemicals from various sources, as previously indicated, the dental staff are highly exposed to disease transmission because of aerosols that are produced during dental procedures and that may be virus- and bacteria-like particles. While there are not many specific studies evidencing with certainty that aerosols generated from dental care led to the transmission of severe acute respiratory syndrome coronavirus 2 (SARS-CoV-2), the spread of different diseases through an airborne route in dental offices has already been documented. Consequently, some standard guidelines for infection control in dental facilities have already been adapted to the SARSCoV-2 pandemic [30] at a European and international level. Given the urgency of the pandemic, but also based on previous evidence regarding the assessment of exposure to influenza virus aerosols during routine patient care, the risk for the transmission of coronaviruses in dental offices must be carefully considered. Moreover, according to some authors, aerosols from dental clinics can play a major role in the transmission of SARS-CoV-2 [30]. 


\section{Results}

\subsection{Health Aspects of Air Pollution with PM}

In 2013, the International Agency for Cancer Research (IARC) classified particulate matter (PM) as carcinogenic to human beings. This was possible as there was enough evidence from both experimental animal studies and clinical studies involving human subjects showing that air pollution with PM is mutagenic and carcinogenic to humans [46]. Exposure to air pollution and especially high levels of particles are associated with the development of cancer through several processes, such as oxidative stress and inflammatory processes at the cellular level [47]. Air pollution accounted for about 5 million deaths in 2017 due to stroke, heart disease, lung cancer, and chronic respiratory disease [48,49]. Relationships between air pollutants, the air quality, and the impact on a human's health are evidenced in Figure 1.

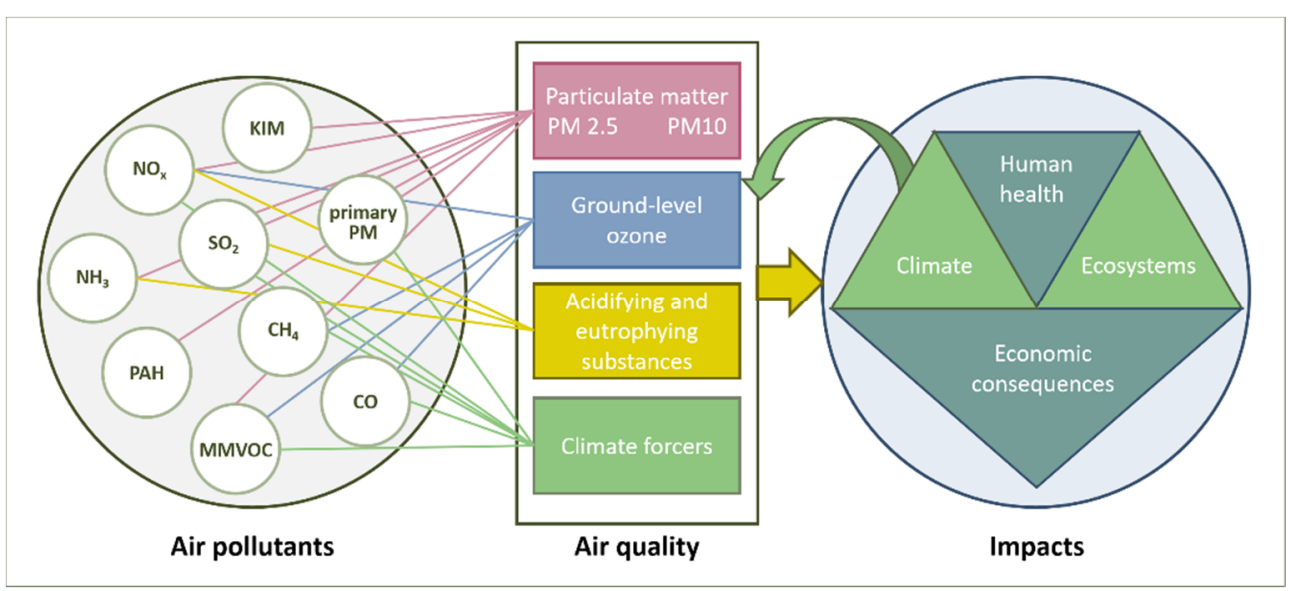

Figure 1. Relationship between air pollutants, the air quality, and the impact on a human's health.

The coarse fraction of suspended particles-PM10 — can affect the airways and lungs. PM2.5 is a more pressing problem because it can enter the respiratory system up to the alveoli and is absorbed into the bloodstream or remains in the lung tissue for long periods of time. Larger particles are mainly deposited in the upper airway [50]. Therefore, in the scientific community, there is important and documented information demonstrating that air pollution with fine particulate matter is one of the risk factors responsible for many health problems, often producing increases in mortality rates [51-53]. According to recent investigations conducted during the pandemic, high levels of air pollution could influence the spreading of the coronavirus disease and the increase of the vulnerability and mortality rates due to SARS-Cov-2 infection [54-56]. Other studies have shown that mortality associated with COVID-19 depends on comorbidities, including cardiovascular problems such as arterial hypertension, diabetes mellitus, obesity, and respiratory conditions including asthma and chronic obstructive pulmonary disease [57-59].

A criterion assessing [60] the ratio of a comparison of PM levels in indoor and outdoor $\mathrm{I} / \mathrm{O}$ environments is an index representing their differences. This ratio displays a high level of variation due to numerous factors, such as building design, locations, and different indoor activities [61]. This ratio has permitted a comparison of the dynamics of indoor and outdoor PM of different buildings. In terms of health, a value of less than 1 shows that the building is needed to reduce outside PM exposure [62].

Human health effects are directly linked to particles' size and influenced by their composition. Some examples referring to the specific negative effects on a human's health correlated with the dimension of the particle aerodynamic diameter (a.d.) are synthetized in Table 2. Concerning the particle dimensions, except for heavy dust (aerodynamic diameter higher than $100 \mu \mathrm{m}$ ) and gas molecules (a.d. $<0.001 \mu \mathrm{m}$ ), particles such as dust, biological contaminants, and particulate contaminants have a size of between 0.05 and $100 \mu \mathrm{m}$. 
Table 2 presents the main negative effects on humans' health, taking into consideration different particle size intervals.

Table 2. Effects on humans' health considering different particle size intervals.

\begin{tabular}{|c|c|c|c|c|}
\hline \multicolumn{3}{|c|}{ Contaminants } & $\begin{array}{l}\text { Aerodynamic } \\
\text { Diameter }(\mu \mathrm{m})\end{array}$ & $\begin{array}{l}\text { Health Effects of Air Pollution from } \\
\text { Particulate Matter }\end{array}$ \\
\hline \multirow{2}{*}{1.} & \multirow{2}{*}{ Dust } & $\begin{array}{c}\text { Suspended } \\
\text { atmospheric dust }\end{array}$ & $0.005-1$ & Chronic obstructive pulmonary disease $[63,64]$ \\
\hline & & Setting dust & $1-100$ & $\begin{array}{l}\text { Respiratory and heart diseases depending on } \\
\text { a.d. size [65] }\end{array}$ \\
\hline \multirow{5}{*}{2.} & \multirow{5}{*}{$\begin{array}{l}\text { Bioaerosols (including } \\
\text { allergen) }\end{array}$} & Pollen & $10-100$ & Asthma, rhinitis, and allergic conjunctivitis [66] \\
\hline & & Mold spores & $8-80$ & Sneezing, watery eyes, and asthma [67] \\
\hline & & House dust & $0.1-10$ & Asthma rhinitis and others [68] \\
\hline & & Bacteria & $0.05-10$ & Various good and bad effects [69] \\
\hline & & Viruses & $0.05-0.5$ & 219 species inducing various diseases $[20,70]$ \\
\hline \multirow{6}{*}{3.} & \multirow{6}{*}{ Particulate contaminants } & Cement dust & $0.5-100$ & Respiratory diseases [71] \\
\hline & & Fly ash & $1-100$ & Respiratory effects [72] \\
\hline & & Oil smoke & $0.05-0.7$ & $\begin{array}{l}\text { Affect respiratory system; after long exposure, } \\
\text { organs can be affected [73] }\end{array}$ \\
\hline & & Smog & $0.01-1.2$ & Respiratory diseases [74] \\
\hline & & Tobacco smoke & $0.01-1$ & $\begin{array}{l}\text { Heart and lung disease, stroke, diabetes, and } \\
\text { chronic pulmonary disease [75] }\end{array}$ \\
\hline & & Soot & $0.01-0.5$ & Inflammatory pulmonary pathway [76] \\
\hline
\end{tabular}

As illustrated in Table 2, all types of particles primarily affect respiratory pathways. Depending on the particle size and exposure time, the effects on humans can stem from inflammation [76] until very aggressive disease, such as lung cancer. In many cases, after long-term exposure, different organs, such as the liver [75,77], are affected. On the other hand, the effects of exposure to certain chemical species on the particle composition, such as black carbon [77], have largely only been studied in the last few years [78].

Short-term exposure could determine the inflammatory reactions at the lung level, adverse effects on the cardiovascular system, increase in the number of cases of chronic obstructive pulmonary disease (COPD), number of hospitalizations, and increased risk of stroke and lung cancer [73].

Long-term exposure leads to a decreased life expectancy through increased cardiopulmonary pathology. There are three important mechanisms [79] by which the particles generate effects on human health: (a) The inhalation of PM leads to an inflammatory response in the lungs and therefore to the release of cytokines (a large group of proteins, peptides, or glycoproteins that are secreted by specific cells of the immune system, involved in the development and regulation of immune responses) in the circulatory system; (b) the second mechanism involves the activation of the neuro-vegetative system, which can affect the blood pressure and heart rate; and (c) the third mechanism involves the direct transport of smaller particles into the blood stream, where they interact with blood vessels and various blood cells. The same mechanisms and effects are encountered in the case of exposure to indoor air pollution [79]. Because there are many sources of allergens or molds in indoor environments, the organic content of PM is high and can lead to allergic and infectious reactions and toxic effects (caused by the inhalation of mycotoxins) [80]. Certain substances, such as arsenic, cadmium, nickel, and polycyclic aromatic hydrocarbons, are genotoxic carcinogens for humans, and thresholds cannot be identified until there are no risks [81].

Indoor exposure to fine particles and health risks are the subject of numerous research studies and ongoing regulatory actions [82]. It is also worth mentioning the criteria development for risk assessment tool selection in work environments and ongoing actions that has occurred in the last two decades [82-85]. Other studies evidence how outdoor pollutant levels may have an impact on the indoor concentrations [86], specifically presenting the 
influences of different chemicals from indoor pollution on humans' health, for instance, the toxic heavy metals that can negatively affect dental health [86]. Dental workers' exposure to PM pollution in indoor environments has been less extensively studied, although exposure in indoor environments to PM is higher than outdoors due to the higher concentrations of $\mathrm{PM}$ in these specific ambientes [87].

The smaller number of studies on the effects of pollution from certain micro-environments (for instance, dental offices and beauty salons) in which activities with a potential impact on some professional categories are carried out requires an intensification of research efforts in this field. Other examples where people spend most of their time indoors and environments that affect sensitive categories of the population are kindergartens, schools, and nursing homes. The following paragraphs illustrate an example of a professional category constantly exposed to high levels of indoor air pollution-dental staff.

\subsection{Indoor Air Pollution in Dentistry}

\subsubsection{Source of Occupational Exposure in Dental Offices and Potential Hazards}

Dental healthcare workers are professionals experiencing multiple exposures to a large range of airborne contamination [88] leading to various occupational diseases. The occupational diseases that appear as a result of indoor pollution increase due to materials and dental equipment services. Indoor particles are a complex mixture of extremely small particles and liquid droplets [89]. Concerning the organic components, these are microorganisms and allergens, while the chemical components can arise from outdoor or building materials and furniture, cleaning products, cigarette smoke, combustion appliances, etc. Short-term exposure to airborne contamination produces health effects, such as headaches, fatigue, and congestion. The health problems after long-term exposure are more aggressive, having consequences such as asthma, lung cancer, and heart disease. In a dental environment with both particulate and gaseous contaminants, combined aerosols are formed. Dental aerosols include components of nasopharyngeal secretions, saliva, plaque, blood, tooth components, and restorative or other materials used in the dental procedures [90]. Dentistry involves the use of dental instruments such as turbine burs, drills, ultrasonic scalers, and abrasion and air polisher units, which are aerosol producers. Airborne contaminants can be released during daily dental procedures, such as drilling and scaling, and during work disinfection. The hazards existing in dentistry are categorized as chemical, physical, biological, mechanical, and psychological [91]. As physical hazards, cuts or puncture wounds from needles and sharp instruments and eye injuries from projectiles can be mentioned [92]. Ionizing (X-rays) and non-ionizing radiation (visible and UV light) [93] which affects dental health care providers is another example of a physical hazard. The noise produced by specific devices used in dentistry, such as highand low-speed hand pieces, ultrasonic scalers, vibrators, and amalgamators, can have negative consequences on humans' health in the form of hearing damage. Noise levels in dental offices and laboratories are considered close to the limit of hearing loss (85.0 dB) [94]. The mechanical-type hazards leading to musculoskeletal problems are due to dentists' improper working posture [95].

Among dental workers, dental technicians are professionals with multiple exposures to various occupational diseases. The occupational diseases appear as a result of indoor pollution increase due to materials and dental equipment services. Chemical hazards can be organic, including gases, resins, and solvents, and inorganic, such as mercury, other metals, and hydrogen peroxide [96]. Biological hazards can occur due to cross contamination, indicating the transmission of infectious agents between patients and staff in clinical environments involving 16 infections and allergens of biological origin [97]. The cross contamination has a high likelihood of being produced through airborne particles in the time that many procedures are performed in dental set up. Aerosols, which are solid and liquid particles with a particle size of $50 \mu \mathrm{m}$ or less, are formed by humans, instruments, or machines [98,99]. Since the generation of aerosols by humans occurs because of breathing, talking, sneezing, or coughing, these aerosols can contaminate large surfaces. In the dental 
microenvironment, there are respiratory penetrable routes with small aerosol particles, with an important pathogenic risk [100]. Certain factors increase the chances of getting infected, including the host's immune response and dose, and the virulence and pathogenicity of the micro-organism.

\subsubsection{Pathogenic Potential of Aerosols}

Dental aerosols contain viruses [101], as well as bacteria and fungi, representing a cross-infection risk factor for dental professionals [102,103]. Important bacterial pathogens are Mycobacterium tuberculosis, Streptococcus pyogenes, Corynebacterium diphtheriae, and Neisseria meningitidis. Such pathogens are transmitted by an airborne route. Dental aerosols have been found to contain virus associated with dangerous diseases, such as the influenza virus, cytomegalovirus, hepatitis virus, herpes simplex virus, and Epstein-Barr virus [104]. The presence of fungi is also reported in studies and found to be an important risk for health care workers [105]. In these circumstances, it is important to identify and implement specific procedures in order to reduce the production of potentially infectious aerosols during dental procedures for protecting both dental workers and patients' health. Various recommendations have been proposed in this regard, according to three defense levels [106,107]. These recommendations include the regular use of personal equipment for protection, pre-procedural mouth rinse protocols, and high evacuation devices. A complete picture of hazards needs to mention stress and excessive work, which can give rise to different psychological problems, especially in the pandemic crisis, during which dentistry has been classified as one of the very high-risk occupations for SARS-Cov-2 transmission [108].

Each type of chemical and material used in laboratories may contaminate the human body in different ways, leading to pathological consequences [109]. An estimation of the chemical hazard of dental technicians presumes dose addition to estimate cumulative risks from exposure to multiple chemicals, considering dose-dependent correlations of the investigated chemicals [108]. Knowing more about contaminants, as well as about the transmission route of different diseases, is the first step in understanding how to manage the occupational hazards and their control in the benefit of health. Table 3 presents a summary of the existing hazards in dental environments and strategies to keep them under control [110].

Table 3. Main potential hazards in dentistry and their control.

\begin{tabular}{|c|c|c|}
\hline & Potential Hazard Due to Indoor Air Pollution & Control Methods \\
\hline 1 & $\begin{array}{c}\text { Exposure to respiratory disease through airborne } \\
\text { transmission }\end{array}$ & $\begin{array}{l}\text { Employee training to use respiratory protective equipment } \\
\text { and apply appropriate cleaning routines }\end{array}$ \\
\hline 2 & $\begin{array}{c}\text { Exposure to environmental biological contaminants from } \\
\text { ventilation systems }\end{array}$ & $\begin{array}{c}\text { Periodic cleaning of ventilation systems in order to detect } \\
\text { and remove the mold }\end{array}$ \\
\hline 3 & $\begin{array}{l}\text { Exposure to respiratory infectious disease through droplet } \\
\text { transmission }\end{array}$ & $\begin{array}{l}\text { Using appropriate medical protection equipment (gloves, } \\
\text { glasses, and masks) }\end{array}$ \\
\hline 4 & $\begin{array}{c}\text { Exposure to disinfectants and cleaning agents in routine } \\
\text { cleaning activities }\end{array}$ & Strict schedule for well-maintained ventilation \\
\hline 5 & $\begin{array}{c}\text { Exposure to metal or silica components in working } \\
\text { materials }\end{array}$ & $\begin{array}{c}\text { Disposal and replacement with an equivalent product } \\
\text { Ensuring local exhaust ventilation }\end{array}$ \\
\hline 6 & Exposure to freshener products & $\begin{array}{l}\text { Replace the air fresheners and sprays with products that } \\
\text { contain less harmful chemicals }\end{array}$ \\
\hline 7 & Exposure to mercury from mercury-containing amalgams & $\begin{array}{c}\text { Replacing mercury-containing products with some less } \\
\text { harmful equivalents }\end{array}$ \\
\hline
\end{tabular}

Although the respiratory system is the prevalent recipient of chemicals as fine powder of silicate, aluminum oxides, acrylic compounds, alloys, and hard metals that are polished, casted, or sandblasted, skin is also exposed to resins and waxes at high temperatures and may be the subject of allergic reactions and contact dermatitis [111]. There are multiple investigations that measure the exposure in dental technicians by various 
methods, including air dust, hair analyses for metal concentrations, the urine elimination of metal, magneto-pneumography, etc., revealing the ferromagnetic alloys deposited in the lung [112,113].

\subsubsection{Chemical Hazards in Dental Workers}

Of the occupational hazards among clinical dental staff, the potential chemical risk cannot be neglected and generally refers to beryllium, silica, natural rubber latex powder, formaldehyde, and mercury. The inhalation of dust containing free silica leads to silicosis, while a small amount of beryllium can lead to chronic beryllium disease (CBD). Generally, all metal components (especially heavy metals) of dental alloys, even in small amounts, involve allergic reactions and/or toxic substances [113]. Polymeric materials, such as acrylics and various resins $[113,114]$ used in restorative dentistry, can act as allergens that induce asthma and parasites on the fingers; this can potentially happen, especially in the case of incomplete polymerization after the setting of chemically initiated materials and adhesives by mixing two components. Free monomers can cause a wide range of skin and eye irritations or mucous membranes. In addition, central nervous system disorders have been evidenced among dental workers. Formaldehyde used for disinfection may cause vomiting and eye irritation, as well as xylene in endodontic retreatment as a gutta-percha solvent [114].

\subsubsection{Dental Technicians and Their High Risk of Developing Occupational Illness Respiratory Diseases}

Dental technicians, being exposed to occupational dust and chemicals, are at a high risk of developing respiratory diseases. It is well-known that silicosis and extrinsic allergic alveolitis can frequently occur among dental staff. The first occupational disease identified in dental technicians was pneumoconiosis [115], reported in 1939. It is caused by the inhalation of dust particles with a $0.2-5 \mu \mathrm{m}$ diameter, mostly silicate, but heavy metals were also identified. Three clinical forms of silicosis are recognized, including acute silicosis, simple chronic silicosis, and chronic silicosis with progressive massive fibrosis [116]. The typical silicosis (simple chronic silicosis) has a late clinical onset, with a period of latency of 10 years of exposure, when small nodules appear in the upper lobes of the lungs. Most of them remain confined to the initial area, rarely forming coalescent nodules. Histological changes in the lung show collagen nodules with chronic inflammatory infiltrate and variable interstitial lung fibrosis. When interstitial fibrosis prevails, underlying interstitial pneumonitis is suspected. With special techniques, such as polarized light, silicate particles can be revealed under the microscope due to their optical properties. For the diagnosis of pneumoconiosis, clinical symptoms are correlated with imagistic investigations for quantifications of lung opacities by chest radiography or high-resolution computer tomography. Because of the multiple agents involved, the pathogenesis of disease is complex, and the burden of each dust component remains under debate. The respiratory function is often impaired, from mild to moderate, depending on the host's biological factors and superimposed risk factors, e.g., smoking. Silicosis is a risk factor for other respiratory diseases, such as dyspnea, tuberculosis, bronchial infections, chronic obstructive pulmonary disease, and heart failure [117].

Dental technicians' pneumoconiosis is most often related to exposure to metallic dusts, specifically cobalt, chromium, and molybdenum, and they may be symptom-free for some time. In vivo exposure to chromium, nickel, and cobalt metals may contribute to genotoxic damage in lymphocytes and exfoliated nasal cells. Dental technicians' pneumoconiosis prevalence varies widely, most probably due to differences in the exposure time, level of metal dust in the dental laboratories, presence of exhaust ventilation, and use of different radiological modalities in diagnosing pneumoconiosis. It may be caused not only by exposure to metal dusts, but also by exposure to silica, plaster, wax and resins, chemical liquids, and methyl methacrylate, currently encountered and used in laboratory work [113]. Open lung biopsy and mineralogical analyses have been performed in two cases of dental tech- 
nicians diagnosed with pneumoconiosis [118]. An increased accumulation of silicon and phosphorus was found in both cases Mineralogical analysis of the lung biopsy disclosed high amounts of chromium, cobalt, and silica particles, suggesting that the combined effects of heavy metal dusts and silica particles generated pneumoconiosis. Occupational exposure to beryllium and aluminum has also been related to pneumoconiosis. Recently, a specific case of pneumoconiosis caused by exposure to indium has been described [116].

Chronic beryllium disease is another pulmonary and systemic granulomatous occupational disease that occurs after prolonged exposure to lower levels of beryllium and may become clinically manifested a long time after the initial exposure. An early diagnosis of chronic beryllium disease may be accomplished by a beryllium lymphocyte proliferation test that can identify beryllium sensitization. For other chemicals, sensitization tests need to be developed, depending on detectable changes in immune cells.

The deposition of silicon and aluminum in lung and salivary glands may be incriminated in developing Sicca syndrome [119].

In addition to the most frequently encountered occupational respiratory diseases, the risk for cancer of the lung, nose, and pleura is presumably increased in dental technicians, knowing that nickel, beryllium, and chromium compounds are on the list of carcinogenic agents published by WHO [120]. Like pneumoconiosis, cancer is also delayed years after exposure. Other occupational diseases that have been reported among dental technicians are asthma and chronic bronchitis [121-125].

\section{Skin Diseases}

Exposure to metals, resins, ceramics, and (meth)acrylates are known to cause skin disorders among those with the occupation. Dental technicians have twice the risk of hand eczema of the general population. In a large retrospective study, most of the dental technicians reported skin exposure to uncured (meth)acrylates and skin contact [126], grinding dust from the same material. Occupational allergic contact dermatitis due to phenylenediamines has also been documented.

Neuropathies

Methyl methacrylate is known to cause sensory disturbances in the fingers of dental technicians who use this resin. Extensive and repeated skin and inhalational exposure of a methyl methacrylate monomer may induce peripheral neuropathy in dental technicians with a long work history [127].

\section{Muscular Disorders}

Dental personnel used to be exposed to the inhalation of metallic mercury vapors. The skeletal muscle of five dental technicians presenting symptoms of chronic exposure to mercury was investigated. Muscle lesions were found, which could have been secondary to neurological involvement, to ischemia caused by capillary lesion, and/or to a direct effect of mercury on muscle protein fibbers [128,129].

Modern dental laboratories try to limit indoor pollution and reduce exposures and diseases among dental technicians, but chemical hazards and equipment such as dust collectors, dust extractors, dental laboratory turbines, dental milling machines, dental casting machines, ovens, drilling machines, and amalgamators are still leading to significant pollution and health risks.

It is important to understand that the health of workers and patients is no longer only an individual-level issue, with its impact and relations being a future part of sustainability which has recently been redefined $[130,131]$.

\section{Conclusions}

The synergistic approach of both indoor and outdoor pollutants is a challenge, especially in the case of the particulate matter concentration, with real implications regarding the short- and long-term measures to be taken in order to reduce the exposure impact, 
specifically in pandemic and post-pandemic periods. The degree of knowledge concerning the link between these two types of pollution is limited. More studies regarding the pandemic, when more people are spending more time in indoor environments, are needed for the development of an appropriate assessment of the indoor/outdoor pollution impact on human health. Even if, concerning the occupational exposures of dentists, modern technologies (such as 3D printing) are replacing the traditional methods in dental laboratories, which may have an important contribution to reducing hazards among professionals, deeper research focused on their exposure to viral particles is required. This is an emergent issue for scientists in the actual context since, according to the present evidence (and considering that routine dental procedures involve aerosol generation), dentistry and dental hygiene are considered two occupations with the most risk of contracting the SARS-CoV-2 virus, with the transmission of this virus taking place via an airborne route.

By identifying and implementing strategies to reduce human exposure (strategies that consider different actions, such as high-volume evacuation, the use of the air-room-cleaning system with high-efficiency particulate filters, regularly maintaining the air-conditioning and ventilation systems, and medical protection for the employees), it can be ensured that human health is protected, improving people's quality of life (and health). The results of this review indicate that the control of aerosols in dental offices must become a standard part of the infection control procedures existing in dental healthcare facilities as exposure to indoor particles can place the dentist at high risk of contracting serious disease. Professionals responsible for designing, planning, and managing specific actions with real consequences for improving the indoor air quality can contribute to public health protection through their work.

Author Contributions: Writing-original draft preparation concerning indoor and outdoor air pollution with fine particles and implications for humans' health, and funding acquisition, D.M.C.; organized the whole research project, designed the working approach, and wrote the main aspects concerning the indoor air pollution, I.D.; writing—original draft preparation concerning PM air pollution and funding acquisition, M.P.; writing-review and editing, P.E.M.L.; writing-original draft preparation concerning the occupational health hazards in dental offices, A.C.D. All authors have read and agreed to the published version of the manuscript.

Funding: This research was funded by the Academy of Romanian Scientists, grant number 23/02.05.2019. The work of Patricia Elena Maria Lungu was funded by the Operational Programme Human Capital of the Ministry of European Funds through the Financial Agreement 51668/09.07.2019, SMIS code 124705, while the work of Diana Mariana Cocârță was partially supported by the Erasmus+ Programme, SafeEngine project, contract no 22020-1-RO01-KA203-080085.

Institutional Review Board Statement: Not applicable.

Informed Consent Statement: Not applicable.

Data Availability Statement: Expert opinion data and any other data are contained within the article.

Conflicts of Interest: The authors declare no conflict of interest.

\section{References}

1. WHO. Novel Coronavirus (2019-nCoV); Situation Report-12; WHO: Geneva, Switzerland, 2020. Available online: https://www. who.int/docs / default-source/coronaviruse/situation-reports /20200201-sitrep-12-ncov.pdf?sfvrsn=273c5d35_2 (accessed on 30 May 2020).

2. Guo, Y.R.; Cao, Q.D.; Hong, Z.S.; Tan, Y.Y.; Chen, S.D.; Jin, H.J.; Tan, K.S.; Wang, D.Y.; Yan, Y. The origin, transmission and clinical therapies on coronavirus disease 2019 (COVID-19) outbreak-An update on the status. Mil. Med. Res. 2020, 7, 11-21. [CrossRef] [PubMed]

3. Singhal, T. A Review of Coronavirus Disease-2019 (COVID-19). Indian J. Pediatr. 2020, 87, 281-286. [CrossRef] [PubMed]

4. Cirrincione, L.; Plescia, F.; Ledda, C.; Rapisarda, V.; Martorana, D.; Moldovan, R.E.; Theodoridou, K.; Cannizzaro, E. COVID-19 Pandemic: Prevention and Protection Measures to be Adopted at the Workplace. Sustainability 2020, 12, 3603. [CrossRef]

5. Zhonghua, L.; Xing, B.; Xue, Z.Z. The epidemiological characteristics of an outbreak of 2019 novel coronavirus diseases (COVID19) in China. Chin. J. Epidemiol. 2020, 41, 145-151. [CrossRef] 
6. Tellier, R.; Li, Y.; Cowling, B.J.; Tang, J.W. Recognition of aerosol transmission of infectious agents: A commentary. BMC Infect. Dis. 2019, 19, 101-110. [CrossRef]

7. Van Doremalen, N.; Bushmaker, T.; Morris, D.H.; Holbrook, M.; Gamble, A.; Williamson, B.; Tamin, A.; Harcourt, J.L.; Thornburg, N.J.; Gerber, S.; et al. Aerosol and surface stability of HCoV-19 (SARS-CoV-2) compared to SARS-CoV-1. N. Eng. J. Med. 2020, 1564-1567. [CrossRef]

8. Pan, M.; Leah, C.; Lednicky, J.A.; Eiguren-Fernandez, A.; Hering, S.; Fan, Z.H.; Wu, C.-Y. Determination of the distribution of infectious viruses in aerosol particles using water-based condensational growth technology and a bacteriophage MS2 model. Aerosol. Sci. Technol. 2019, 53, 583-593. [CrossRef]

9. Pan, M.; Lednicky, J.A. Collection, particle sizing and detection of airborne viruses. J. Appl. Microbiol. 2019, $127,1596-1611$. [CrossRef]

10. Wang, M.; Cao, R.; Zhang, L.; Yang, X.; Liu, J.; Xu, M.; Shi, Z.; Hu, Z.; Zhong, W.; Xiao, G. Remdesivir and chloroquine effectively inhibit the recently emerged novel coronavirus (2019-nCoV) in vitro. Cell Res. 2020, 30, 269-271. [CrossRef]

11. Gordon, C.J.; Tchesnokov, E.P.; Feng, J.Y.; Porter, D.P.; Gotte, M. The antiviral compound remdesivir potently inhibits RNAdependent RNA polymerase from Middle East respiratory syndrome coronavirus. J. Biol. Chem. 2020, 295, 4773-4779. [CrossRef]

12. Ye, X.T.; Luo, Y.L.; Xia, S.C.; Sun, Q.F.; Ding, J.G.; Zhou, Y.; Chen, W.; Wang, X.F.; Zhang, W.W.; Du, W.J.; et al. Clinical efficacy of lopinavir/ritonavir in the treatment of Coronavirus disease 2019. Eur. Rev. Med. Pharm. Sci. 2020, 24, 3390-3396. [CrossRef]

13. Setti, L.; Passarini, F.; De Gennaro, G.; Di Gilio, A.; Palmisani, J.; Buono, P.; Fornari, G.; Perrone, M.G.; Piazzalunga, A.; Barbieri, P.; et al. Airborne Transmission Route of COVID-19: Why 2 Meters / 6 Feet of Inter-Personal Distance Could Not Be Enough. Int. J. Environ. Res. Public Health 2020, 17, 2932. [CrossRef] [PubMed]

14. Morawska, L.; Milton, D.K. It is Time to Address Airborne Transmission of COVID-19. Clin. Infect. Dis. 2020, 71, 2311-2313. [CrossRef]

15. Wu, X.; Nethery, R.C.; Sabath, B.M.; Braun, D.; Dominici, F. Exposure to air pollution and COVID-19 mortality in the United States: A nationwide cross-sectional study; Version 2. medRxiv 2020. [CrossRef]

16. Ritchie, H.; Roser, M. Causes of Death. Available online: https:/ / ourworldindata.org/causes-of-death (accessed on 30 May 2020).

17. Hendryx, M.; Islam, M.S.; Dong, G.-H.; Paul, G. Air Pollution Emissions 2008-2018 from Australian Coal Mining: Implications for Public and Occupational Health. Int. J. Environ. Res. Public Health 2020, 17, 1570. [CrossRef]

18. Barthelemy, J.; Sanchez, K.; Miller, M.R.; Khreis, H. New Opportunities to Mitigate the Burden of Disease Caused by Traffic Related Air Pollution: Antioxidant-Rich Diets and Supplements. Int. J. Environ. Res. Public Health 2020, 17, 630. [CrossRef]

19. Kumar, B.; Verma, K.; Kulshrestha, U. Deposition and Mineralogical Characteristics of Atmospheric Dust in relation to Land Use and Land Cover Change in Delhi (India). Geogr. J. 2014, 2014. [CrossRef]

20. Kiselev, D.; Matsvay, A.; Abramov, I.; Dedkov, V.; Shipulin, G.; Khafizov, K. Current Trends in Diagnostics of Viral Infections of Unknown Etiology. Viruses 2020, 12, 211. [CrossRef]

21. United States Department of Labor Occupational Safety and Health Administration. Dentistry Workers and Employers. 2020. Available online: https:/ /www.osha.gov/SLTC/covid-19/dentistry.html (accessed on 14 December 2020).

22. Harrel, S.K.; Molinari, J. Cover story, Aerosols and splatter in dentistry, A brief review of the literature and infection control implications. Clinical Practice. JADA 2004, 135, 429-437. [CrossRef]

23. Abichandani, S.; Nadige, R. Cross contamination in dentistry: A comprehensive overview. J. Educ. Ethics Dent. 2012, 2, 3-9. [CrossRef]

24. Merte, J.L.; Kroll, C.M.; Collins, A.S.; Melnick, A.L. An epidemiologic investigation of occupational transmission of Mycobacterium tuberculosis infection to dental health care personnel. Infection prevention and control implications. JADA 2014, 145, 464-471. [CrossRef] [PubMed]

25. Zemouri, C.; Awad, S.F.; Volgenant, C.M.C.; Crielaard, W.; Laheij, A.M.G.A.; De Soet, J.J. Modeling of the Transmission of Coronaviruses, Measles Virus, Influenza Virus, Mycobacterium tuberculosis, and Legionella Pneumophila in dental clinics. J. Dent. Res. 2020, 99, 1192-1198. [CrossRef] [PubMed]

26. Peng, Z.; Jimenez, J.L. Exhaled $\mathrm{CO}_{2}$ as COVID-19 infection risk proxy for different indoor environments and activities. MedRxiv 2020, 1-9. [CrossRef]

27. Plog, J.; Wu, J.; Dias, Y.J.; Mashayek, F.; Cooper, L.F.; Yarin, A.L. Reopening dentistry after COVID-19: Complete suppression of aerosolization indental procedures by viscoelastic Medusa Gorgo. Phys. Fluids 2020, 32, 083111. [CrossRef]

28. Wallace, L.A. The Total Exposure Assessment Methodology (TEAM) Study: Summary and Analysis; Environmental Protection Agency (EPA): Washington, DC, USA, 1987. Available online: https:/ / nepis.epa.gov / Exe/ZyPDF.cgi/2000UC5T.PDF?Dockey=2000UC5 T.PDF (accessed on 14 December 2020).

29. Cincinelli, A.; Martellini, T. Editorial Indoor Air Quality and Health. Int. J. Environ. Res. Public Health 2017, 14, 1286. [CrossRef]

30. Volgenant, C.M.C.; Persoon, I.F.; De Ruijter, R.A.G.; De Soet, J.J.H. Infection control in dental health care during and after the SARS-CoV-2 outbreak. Oral Dis. 2020, 1-10. [CrossRef]

31. Shandilya, K.K.; Khare, M. Particulate Matter: Sources, Emission Rates and Health Effects. In Environmental and Agricultural Researcher Biographical Sketches and Research Summaries, Environmental Research Advances, 1st ed.; Cacioppo, L.T., Ed.; Nova Science Publishers: Hauppauge, NJ, USA, 2014; Volume 1, pp. 305-306.

32. Massey, D.; Kulshrestha, A.; Masih, J.; Taneja, A.B.E.J. Seasonal trends of PM 10, PM 5.0, PM 2.5 \& PM 1.0 in indoor and outdoor environments of residential homes located in North-Central India. Build. Environ. 2012, 47, 223-231. [CrossRef] 
33. Alberdi, E.; Alvarez, I.; Hernández, H.; Oyarbide-Zubillaga, A.; Goti, A. Analysis of the Air Quality of the Basque Autonomous Community Using Spatial Interpolation. Sustainability 2020, 12, 4164. [CrossRef]

34. Urrutia, K.; Stendorf, S.; Molina, P.; Flores, I. Smart zero carbon city: Key factors towards smart urban decarbonization. DYNA 2019, 94, 676-683. [CrossRef]

35. Muleski, G.E.; Cowherd, C., Jr.; Kinsey, J.S. Particulate Emissions from Construction Activities. J. Air Waste Manag. Assoc. 2005, 55, 772-783. [CrossRef]

36. Chang, L.T.C.; Scorgie, Y.; Duc, H.N.; Monk, K.; Fuchs, D.; Trieu, T. Major Source Contributions to Ambient PM2.5 and Exposures within the New SouthWales Greater Metropolitan Region. Atmosphere 2019, 10, 138. [CrossRef]

37. Xue, H.; Liu, G.; Zhang, H.; Hu, R.; Wang, X. Similarities and differences in PM10 and PM2.5 concentrations, chemical compositions and sources in Hefei City, China. Chemosphere 2019, 220, 760-765. [CrossRef] [PubMed]

38. Air Quality Standards, European Commission; Ambient Air Quality Standards (GB3095-2012), Ministry of Environmental Protection and General Administration of Quality Supervision, Inspection and Quarantine of China. 2012. Available online: http: / / english.mee.gov.cn/Resources/standards / Air_Environment/quality_standard1/201605/t20160511_337502.shtml (accessed on 5 August 2020).

39. WHO. Household Air Pollution and Health. Available online: https://www.who.int/news-room/fact-sheets/detail/householdair-pollution-and-health (accessed on 5 August 2020).

40. Sarafraz, M.; Sadani, M.; Teimouri, F. Indoor Aerosols: A Serious Threat for Human Health. J. Environ. Health Sustain. Dev. 2018, 3, 488-491.

41. Schieweck, A.; Uhde, E.; Salthammer, T.; Salthammer, L.C.; Morawska, L.; Mazaheri, M.; Kumar, P. Smart homes and the control of indoor air quality. Renew. Sustain. Energ. Rev. 2018, 94, 705-718. [CrossRef]

42. Destaillats, H.; Maddalena, R.L.; Singer, B.C.; Hodgson, A.T.; Mc Kone, T.E. Indoor pollutants emitted by office equipment: A review of reported data and information needs. Atmos. Environ. 2008, 42, 1371-1388. [CrossRef]

43. De Gennaro, G.; Dambruoso, P.R.; Loiotile, A.D.; Di Gilio, A.; Giungato, P.; Tutino, M.; Marzocca, A.; Mazzone, A.; Palmisani, J.; Porcelli, F. Indoor air quality in schools. Environ. Chem. Lett. 2014, 12, 467-482. [CrossRef]

44. European Committee for Standardization (CEN). UNE EN 12341:2015. Ambient Air. In Standard Gravimetric Measurement Method for the Determination of the PM10 and PM2.5 Mass Concentration of Suspended Particulate Matter; European Committee for Standardization: Brussel, Belgium, 2015. Available online: https://standards.iteh.ai/catalog/standards/cen/7ad508ad-33bd-4e4 1-942b-c52ddeb6d44d/en-12341-2014, (accessed on 5 August 2020).

45. Environmental Protection Agency (EPA). Environmental Hazards in the Home; Environmental Protection Agency (EPA): Washington, DC, USA, 2016. Available online: http://library.hsh.com/articles/homeowners-repeat-buyers/environmental-hazards-in-thehome/ (accessed on 5 August 2020).

46. Park, M.; Joo, H.S.; Lee, K.; Jang, M.; Kim, S.D.; Kim, I.; Borlaza, L.J.S.; Lim, H.; Shin, H.; Chung, K.H.; et al. Differential toxicities of fine particulate matters from various sources. Sci. Rep. 2018, 8, 17007-17018. [CrossRef]

47. Brown, J.S.; Gordon, T.; Price, O.; Asgharian, B. Thoracic and respirable particle definitions for human health risk assessment. Part. Fibre Toxicol. 2013, 10, 12-24. [CrossRef]

48. Hamra, G.B.; Guha, N.; Cohen, A.; Laden, F.; Raaschou-Nielsen, O.; Samet, J.M.; Vineis, P.; Forastiere, F.; Saldiva, P.; Yorifuji, T.; et al. Outdoor Particulate Matter Exposure and Lung Cancer: A Systematic Review and Meta-Analysis. Environ. Health Perspect. 2014, 122, 906-911. [CrossRef]

49. Brauer, M.; Amann, M.; Burnett, R.T.; Cohen, A.; Dentener, F.; Ezzati, M.; Henderson, S.B.; Krzyzanowski, M.; Martin, R.V.; Van Dingenen, R.; et al. Exposure assessment for estimation of the global burden of disease attributable to outdoor air pollution. Environ. Sci Technol. 2012, 46, 652-660. [CrossRef]

50. Jia, Y.Y.; Wang, Q.; Liu, T. Toxicity Research of PM2.5 Compositions in Vitro. Int. J. Environ. Res. Public Health 2017, 14, 232. [CrossRef] [PubMed]

51. Burnett, R.T.; Pope III, C.A.; Ezzati, M.; Olives, C.; Lim, S.S.; Mehta, S.; Shin, H.H.; Singh, G.; Hubbell, B.; Brauer, M.; et al. An integrated risk function for estimating the global burden of disease attributable to ambient fine particulate matter exposure. Environ. Health Perspect. 2014, 122, 397-403. [CrossRef] [PubMed]

52. Lelieveld, J.; Evans, J.S.; Fnais, M.; Giannadaki, D.; Pozzer, A. The contribution of outdoor air pollution sources to premature mortality on a global scale. Nature 2015, 525, 367-371. [CrossRef] [PubMed]

53. Lelieveld, J.; Klingmueller, K.; Pozzer, A.; Pöschl, U.; Fnais, M.; Daiber, A.; Münzel, T. Cardiovascular disease burden from ambient air pollution in Europe reassessed using novel hazard ratio functions. Eur. Heart J. 2019, 40, 1590-1596. [CrossRef]

54. Pozzer, A.; Dominici, F.; Haines, A.; Witt, C.; Münzel, T.; Lelieveld, J. Regional and global contributions of air pollution to risk of death from COVID-19. Cardiovasc. Res. 2020, 116, 2247-2253. [CrossRef]

55. Contini, D.; Costabile, F. Does air pollution influence COVID-19 outbreaks? Atmosphere 2020, 11, 377. [CrossRef]

56. Wang, C.; Horby, P.W.; Hayden, F.G.; Gao, G.F. A novel coronavirus outbreak of global health concern. Lancet 2020, 395, 470-473. [CrossRef]

57. Zhou, P.; Yang, X.L.; Wang, X.G.; Hu, B.; Zhang, L.; Zhang, W.; Si, H.R.; Zhu, Y.; Li, B.; Huang, C.L.; et al. A pneumonia outbreak associated with a new coronavirus of probable bat origin. Nature 2020, 579, 270-273. [CrossRef]

58. Lelieveld, J.; Pozzer, A.; Pöschl, U.; Fnais, M.; Haines, A.; Münzel, T. Comparison of mortality from ambient air pollution with other risk factors: A worldwide perspective. Cardiovasc. Res. 2020, 116, 1910-1917. [CrossRef] 
59. Miller, M.R. Oxidative stress and the cardiovascular effects of air pollution. Free Radic. Biol. Med. 2020, 151, 69-87. [CrossRef]

60. Meng, Q.Y.; Turpin, B.J.; Korn, L.; Weisel, C.P.; Morandi, M.; Colome, S.; Zhang, J.; Stock, T.; Spektor, D.; Winer, A. Influence of ambient (outdoor) sources on residential indoor and personal PM2.5 concentrations: Analyses of RIOPA data. J. Expo. Sci. Environ. Epidemiol. 2005, 15, 17-28. [CrossRef] [PubMed]

61. Chatoutsidou, S.E.; Ondráček, J.; Tesar, O.; Tørseth, K.; Ždímal, V.; Lazaridis, M. Indoor/outdoor particulate matter number and mass concentration in modern offices. Build. Environ. 2015, 92, 462-474. [CrossRef]

62. Jeričević, A.; Gašparac, G.; Mikulec, M.M.; Kumar, P.; Prtenjak, M.T. Identification of diverse air pollution sources in a complex urban area of Croatia. J. Environ. Manag. 2019, 243, 67-77. [CrossRef] [PubMed]

63. Moreno, T.; Trechera, P.; Querol, X.; Lah, R.; Johnson, D.; Wrana, A.; Williamson, B. Trace element fractionation between PM10 and PM2.5 in coal mine dust: Implications for occupational respiratory health. Int. J. Coal Geol. 2019, 203, 52-59. [CrossRef]

64. Cullinan, P. Occupation and chronic obstructive pulmonary disease (COPD). Br. Med. Bull. 2012, 104, 143-161. [CrossRef] [PubMed]

65. Khan, R.K.; Mark, A. Strand Road dust and its effect on human health: A literature review. Epidemiol. Health 2018, 40, e2018013. [CrossRef]

66. Berger, U.; Karatzas, K.; Jaeger, S.; Voukantsis, D.; Sofiev, M.; Brandt, O.; Zuberbier, T.; Bergmann, K.C. Personalized pollen-related symptom-forecast information services for allergic rhinitis patients in Europe. Allergy 2013, 68, 963-965. [CrossRef]

67. Weinhold, B. A Spreading Concern: Inhalational Health Effects of Mold. Environ. Health Perspect. 2007, 115, A300-A305. [CrossRef]

68. Acevedo, N.; Zakzuk, J.; Caraballo, L. House Dust Mite Allergy Under Changing Environments Allergy Asthma. Immunol. Res. 2019, 11, 450-469. [CrossRef]

69. Wang, H.; Wei, C.-X.; Min, L.; Zhu, L.-Y. Good or bad: Gut bacteria in human health and diseases. Biotechnol. Biotechnol. Equip. 2018, 32, 1075-1080. [CrossRef]

70. Woolhouse, M.; Scott, F.; Hudson, Z.; Howey, R.; Chase, M. Topping Human viruses: Discovery and emergence. Philos. Trans. R. Soc. B Biol. Sci. 2012, 367, 2864-2871. [CrossRef] [PubMed]

71. Hommi, Y.B.S.; Abdelaziz, M.S.; Ahmad, H.G. Effect of Occupational Cement Dust Pollution on The Respiratory Epithelium in Amran Cement Factory. J. Sci. Technol. 2013, 15, 25-32. [CrossRef]

72. Kurda, R.; Silvestre, J.D.; De Brito, J. Toxicity and environmental and economic performance of fly ash and recycled concrete aggregates use in concrete: A review. Heliyon 2018, 4, 1-45. [CrossRef] [PubMed]

73. Svedahl, S.; Svendsen, K.; Qvenild, T.; Sjaastad, A.K.; Hilt, B. Short term exposure to cooking fumes and pulmonary function. J. Occup. Med. Toxicol. 2009, 4, 9-17. [CrossRef] [PubMed]

74. Yang, L.E.; Hoffmann, P.; Scheffran, J. Health impacts of smog pollution: The human dimensions of exposure. Lancet Planet. Health 2017, 1, E132-E133. [CrossRef]

75. Bellisario, V.; Piccioni, P.; Bugiani, M.; Squillacioti, G.; Levra, S.; Gulotta, C.; Mengozzi, G.; Perboni, A.; Grignani, E.; Bono, R. Tobacco Smoke Exposure, Urban and Environmental Factors as Respiratory Disease Predictors in Italian Adolescents. Int. J. Environ. Res. Public Health 2019, 16, 4048. [CrossRef]

76. Niranjan, R.; Thakur, A.K. The Toxicological Mechanisms of Environmental Soot (Black Carbon) and Carbon Black: Focus on Oxidative Stress and Inflammatory Pathways. Front. Immunol. 2017, 8, 1-20. [CrossRef]

77. Kim, K.-H.; Kabir, E.; Kabir, S. A review on the human health impact of airborne particulate matter. Environ. Int. 2015, 74, 136-143. [CrossRef]

78. Riediker, M.; Zink, D.; Kreyling, W.; Oberdörster, G.; Elder, A.; Graham, U.; Lynch, I.; Duschl, A.; Ichihara, G.; Ichihara, S.; et al. Particle toxicology and health-Where are we? Part. Fibre Toxicol. 2019, 16, 19-52. [CrossRef]

79. Abelsohn, A.; Stieb, D.M. Health effects of outdoor air pollution: Approach to counselling patients using the Air Quality Health Index. Can. Fam. Physician 2011, 57, 881-887.

80. Peraica, M.; Radic, B.; Lucic, A.; Pavlovic, M. Toxic effects of mycotoxins in humans. Bull. World Health Organ. 1999, 77, 754-766. [PubMed]

81. Kim, H.S.; Kim, Y.J.; Seo, Y.R. An Overview of Carcinogenic Heavy Metal: Molecular Toxicity Mechanism and Prevention. J. Cancer Prev. 2015, 20, 232-240. [CrossRef] [PubMed]

82. Brocklehurst, P.; Ashley, J.; Tickle, M. Patient assessment in general dental practice-Risk assessment or clinical monitoring? Br. Dent. J. 2011, 210, 351-354. [CrossRef] [PubMed]

83. Moraru, R.I.; Babut, G.B.; Cioca, L.I. Rationale and criteria development for risk assessment tool selection in work environments. Environ. Eng. Manag. J. 2014, 13, 1371-1376. [CrossRef]

84. Cioca, L.I.; Moraru, R.I.; Băbuţ, G.B. A framework for organisational characteristic assessment and their influences on safety and health at work. In Proceedings of the 15th International Scientific Conference the Knowledge Based Organization: Management, Land Forces Academy, Sibiu, Romania, 26-28 November 2009; Volume 2, pp. 43-48.

85. Helmis, C.G.; Tzoutzas, J.; Flocas, H.A.; Halios, C.H.; Stathopoulou, O.I.; Assimakopoulos, V.D.; Panis, V.; Apostolatou, M.; Sgouros, G.; Adam, E. Indoor air quality in a dentistry clinic. Sci. Total Environ. 2007, 377, 349-365. [CrossRef]

86. Demetrescu, I.; Luca, R.; Ionita, D.; Prodana, M. Evaluation of heavy metals of temporary teeth from areas with different pollution level. Mol. Cryst. Liq. Cryst. 2010, 523, 73-81. [CrossRef] 
87. Bo, M.; Salizzoni, P.; Clerico, M.; Buccolieri, R. Assessment of Indoor-Outdoor Particulate Matter Air Pollution: A Review. Atmosphere 2017, 8, 136. [CrossRef]

88. Anjum, A.; Hosein, M.; Butt, S.A.; Fakhuruddin. Cross Infection in Dentistry and the Dental Aerosols-A Potential Health Hazard. Pak. J. Med. Dent. 2020, 9, 70-75.

89. Azari, M.; Ghadjari, A.; Massoudinejad, M.; Nasiree, N.F. Airborne Microbial Contamination of Dental Units. Tanaffos 2008, 7, 4-57.

90. Bhuvaneswari, P. Aerosols-A concern for dentists. Res. J. Pharm Technol. 2014, 7, 938-941.

91. Raja, K.; Tilak, A.H. Occupational hazards in dentistry and its control measure-A review. World J. Pharm. Pharm. Sci. 2014, 3, 397-415.

92. Soaita, C. Identifying occupational riscks in dentistry. Proc. Technol. 2014, 12, 558-565. [CrossRef]

93. Bruzell, R.E.M.; Jacobsen, N.; Hensten-Pettersen, A. Health hazards associated with curing light in the dental clinic. Clin. Oral Investig. 2004, 8, 113-117. [CrossRef] [PubMed]

94. Mojarad, F.; Massum, T.; Samavat, H. Noise Levels in Dental Offices and Laboratories in Hamedan, Iran. J. Dent. 2009, 6, 181-185.

95. Pîrvu, C.; Pătraşcu, I.; Pîrvu, D.; Ionescu, C. The dentist's operating posture-Ergonomic aspects. J. Med. Life 2014, 7, 177-182. [PubMed]

96. Ayatollahi, J.; Ayatollahi, F.; Ardekani, A.M.; Bahrololoomi, R.; Ayatollahi, J.; Ayatollahi, A.; Owlia, M.B. Occupational hazards to dental staff. Dent. Res. J. 2012, 9, 2-7. [CrossRef]

97. Yoo, Y.J.; Kwak, E.J.; Jeong, K.M.; Baek, S.H.; Baek, Y.S. Knowledge, attitudes and practices regarding methicillin-resistant Staphylococcus aureus (MRSA) infection control and nasal MRSA carriage rate among dental health-care professionals. Int. Dent. J. 2018, 68, 359-366. [CrossRef]

98. Zemouri, C.; De Soet, H.; Crielaard, W.; Laheij, A. A scoping review on bio-aerosols in healthcare and the dental environment. PLoS ONE 2017, 12, e0178007. [CrossRef]

99. Singh, A.; Manjunath, R.S.; Singla, D.; Bhattacharya, H.S.; Sarkar, A.; Chandra, N. Aerosol, a health hazard during ultrasonic scaling: A clinico-microbiological study. Indian J. Dent. Res. 2016, 27, 160-162. [CrossRef]

100. Kobza, J.; Pastuszka, J.; Bragoszewska, E. Do exposures to aerosols pose a risk to dental professionals? Occup. Med. 2018, 68, 454-458. [CrossRef]

101. Gandolfi, M.G.; Zamparini, F.; Spinelli, A.; Sambri, V.; Prati, C. Risks of Aerosol Contamination in Dental Procedures during the Second Wave of COVID-19-Experience and Proposals of Innovative IPC in Dental Practice. Int. J. Environ. Res. Public Health 2020, 17, 8954. [CrossRef] [PubMed]

102. Ge, Z.Y.; Yang, L.M.; Xia, J.J.; Fu, X.H.; Zhang, Y.Z. Possible aerosol transmission of COVID-19 and special precautions in dentistry. J. Zhejiang Univ. 2020, 21, 361-368. [CrossRef] [PubMed]

103. Volgenant, C.; De Soet, J. Cross-transmission in the dental office: Does this make you ill? Curr. Oral Health Rep. 2018, 5, 221-228. [CrossRef] [PubMed]

104. Ramich, T.; Eickholz, P.; Wicker, S. Work-related infections in dentistry: Risk perception and preventive measures. Clin. Oral Investig. 2017, 21, 2473-2479. [CrossRef]

105. Holloman, J.L.; Mauriello, S.M.; Pimenta, L.; Arnold, R.R. Comparison of suction device with saliva ejector for aerosol and spatter reduction during ultrasonic scaling. J. Am. Dent. Assoc. 2015, 146, 27-33. [CrossRef] [PubMed]

106. Gopalakrishnan, D.; Juluri, R.; Srihari, J.; Viswanathan, V. Comparing the efficacy of two mouth rinses in reducing bacterial aerosol contamination. J. Dent. Oral Health 2017, 4, 1-4.

107. Sawhney, A.; Venugopal, S.; Babu, G.R.; Garg, A.; Mathew, M.; Yadav, M.; Gupta, B.; Tripathi, S. Aerosols how dangerous they are in clinical practice. J. Clin. Diagn. Res. 2015, 9, ZC52-ZC57. [CrossRef]

108. Zadeh, A.N.; Dufresne, A. Chemical Hazards in Dental Laboratories. Indoor Built. Environ. 1998, 7, 146-155. [CrossRef]

109. Fasunloro, A.; Owotade, F.J. Occupational hazards among clinical dental staff. J. Contemp. Dent. Pract. 2004, 5, 134-152. [CrossRef]

110. Prashant, B.; Firoza, S.; Jaiswal, J.N.; Bansal, A. Occupational hazards among dentists: A review of literature. J. Int. Med. Dent. Res. 2011, 4, 87-93.

111. Leggat, P.A.; Kedjarune, U.; Smith, D.R. Occupational Health Problems in Modern Dentistry: A Review. Ind. Health 2007, 45, 611-621. [CrossRef] [PubMed]

112. Rustemeyer, T.; Frosch, P.J. Occupational Contact Dermatitis in Dental Personnel. Kanerva's Occup. Dermatol. 2020, 1879-1890. [CrossRef]

113. Zhang, X.; Wei, L.C.; Wu, B.; Yu, L.Y.; Wang, X.P.; Liu, Y. A comparative analysis of metal allergens associated with dental alloy prostheses and the expression of HLA-DR in gingival tissue. Mol. Med. Rep. 2016, 13, 91-98. [CrossRef] [PubMed]

114. Nilsen, B.W.; Jensen, E.P.H.; Örtengren, U.; Michelsen, V.B. Airborne exposure to gaseous and particle-associated organic substances in resin-based dental materials during restorative procedures. Eur. J. Oral Sci. 2019, 127, 1-10. [CrossRef]

115. Polednik, B. Aerosol and bioaerosol particles in a dental office. Environ. Res. 2014, 134, 405-409. [CrossRef]

116. Okamoto, M.; Tominaga, M.; Shimizu, S.; Yano, C.; Masuda, K.; Nakamura, M.; Zaizen, Y.; Nouno, T.; Sakamoto, S.; Yokoyama, M.; et al. Dental Technicians' Pneumoconiosis. Intern. Med. 2017, 56, 3323-3326. [CrossRef]

117. Inayati, E.; Salim, S.; Harwasih, S.; Indiani, S.R. Levels of crystalline silica dust in dental laboratorium of Dental Health Technology. Dent. J. 2015, 48, 183-187. [CrossRef] 
118. Barnes, H.; Goh, N.S.L.; Leong, T.L.; Hoy, R. Silica-associated lung disease: An old-world exposure in modern industries. Respirology 2019, 24, 1165-1175. [CrossRef]

119. Torres, P.P.T.S.; Marchiori, E.; Pinto, S.A.; Rabahi, M.F. Wood charcoal dust pneumoconiosis. Rev. Port. Pneumol. 2017, 23, 233-234. [CrossRef]

120. Astudillo, L.; Sailler, L.; Ecoiffier, M.; Giron, J.; Couret, B.; Arlet-Suau, E. Exposure to silica and primary Sjögren's syndrome in a dental technician. Rheumatology 2003, 42, 1268-1269. [CrossRef]

121. WHO. IARC Monographs on the Identification of Carcinogenic Hazards to Humans. 2020. Available online: https:/ / monographs. iarc.fr/ (accessed on 5 August 2020).

122. Singh, T.; Bello, B.; Jeebhay, M. Risk factors associated with asthma phenotypes in dental healthcare workers. Am. J. Ind. Med. 2013, 56, 90-99. [CrossRef] [PubMed]

123. Tarlo, S.M. Occupational exposures and adult asthma. Immunol. Allergy Clin. 2008, 28, 563-576. [CrossRef] [PubMed]

124. Lugović-Mihić, L.; Ferček, I.; Duvančić, T.; Bulat, V.; Ježovita, J.; Novak-Bilić, G.; Šitum, M. Occupational contact dermatitis amongst dentists and dental technicians. Acta Clin. Croat. 2016, 55, 293-300. [CrossRef] [PubMed]

125. Rai, R.; Dinakar, D.; Kurian, S.S.; Bndoo, Y.A. Investigation of contact allergy to dental materials by patch testing. Indian Derm. Online J. 2014, 5, 282-286. [CrossRef] [PubMed]

126. Aalto-Korte, K.; Alanko, K.; Kuuliala, O.; Jolanki, R. Methacrylate and acrylate allergy in dental personnel. Contact Dermat. 2007, 57, 324-330. [CrossRef] [PubMed]

127. Donaghy, M.; Rushworth, G.; Jacobs, J.M. Generalized peripheral neuropathy in a dental technician exposed to methyl methacrylate monomer. Neurology 1991, 41, 1112-1116. [CrossRef]

128. Sakzewski, L.; Naser-ud-Din, S. Work-related musculoskeletal disorders in dentists and orthodontists: A review of the literature. Work 2014, 48, 37-45. [CrossRef]

129. Jirau-Colón, H.; González-Parrilla, L.; Martinez-Jiménez, J.; Adam, W.; Jiménez-Velez, B. Rethinking the Dental Amalgam Dilemma: An Integrated Toxicological Approach. Int. J. Environ. Res. Public Health 2019, 16, 1036. [CrossRef]

130. Hakovirta, M.; Denuwara, N. How COVID-19 Redefines the Concept of Sustainability. Sustainability 2020, 12, 3727. [CrossRef]

131. Cioca, L.I.; Moraru, R.L.; Băbuț, G.B.; Ungureanu, N.S. Integrating Risk Analysis with Safety Dyagnostic In Complex Industrial Systems: Modeling Hazard. Acta Univ. Cibiniensis 2015, 66. [CrossRef] 